\title{
DIGNITY
}

Dignity: A Journal of Analysis of Exploitation and Violence

\section{A Feminist Challenge to Transgenderism. A Review of Doublethink: A Feminist Challenge to Transgenderism by Janice G. Raymond}

Esohe Aghatise

Associazione Iroko Onlus, esoheaghatise@tin.it

Follow this and additional works at: https://digitalcommons.uri.edu/dignity

Part of the Bioethics and Medical Ethics Commons, Gender and Sexuality Commons, Human Factors Psychology Commons, Inequality and Stratification Commons, Medical Humanities Commons, Psychiatry and Psychology Commons, Public Health Commons, and the Social Justice Commons

\section{Recommended Citation}

Aghatise, Esohe (2022) "A Feminist Challenge to Transgenderism. A Review of Doublethink: A Feminist Challenge to Transgenderism by Janice G. Raymond," Dignity: A Journal of Analysis of Exploitation and Violence: Vol. 7: Iss. 1, Article 5. https://doi.org/10.23860/dignity.2022.07.01.05

This Book Review is brought to you for free and open access by DigitalCommons@URI. It has been accepted for inclusion in Dignity: A Journal of Analysis of Exploitation and Violence by an authorized editor of DigitalCommons@URI. For more information, please contact digitalcommons-group@uri.edu. 


\section{A Feminist Challenge to Transgenderism. A Review of Doublethink: A Feminist Challenge to Transgenderism by Janice $\mathrm{G}$. Raymond}

\section{Keywords}

transgender, Janice Raymond, doublethink, gender dysphoria, patriarchy, dissent, cis-women, medical intervention

\section{Creative Commons License}

\section{(c) $($ ) $\Theta \Theta$}

This work is licensed under a Creative Commons Attribution-Noncommercial-No Derivative Works 4.0 License. 


\title{
DIGNITY
}

A JOURNAL OF ANALYSIS

OFEXPLOITATIONAND VIOLENCE

Volume 7, Issue 1, Article 5, 2022

https://doi.org/10.23860/dignity.2022.07.01.05

\section{A FEMINIST CHALLENGE TO TRANSGENDERISM}

\section{A REVIEW OF}

\author{
DOUBLETHINK: A FEMINIST CHALLENGE TO \\ TRANGENDERISM BY JANICE G. RAYMOND
}

\author{
Esohe Aghatise \\ Associazione Iroko Onlus, Italy
}

\section{KEYWORDS}

transgender, Janice Raymond, doublethink, gender dysphoria, patriarchy, dissent, cis-women, medical intervention

$J_{\text {is }}^{\text {A }}$

ANICE RAYMOND'S BOOK DOUBLETHINK: A FEMINIST CHALLENGE TO TRANSGENDERISM is an on-point expose of the corrosive harm posed by Transgenderism and the transgender ideology to society as a whole and most especially to women. It builds on her previous and equally groundbreaking book, The Transsexual Empire: The Making of the She-Male, published in 1979, which warned of the risks of the medicalisation of gender dissatisfaction and its reinforcement of patriarchal gender stereotypes and roles. Back then, she warned of the medical and other consequences of the surgical mutilation of healthy bodies inherent in transsexual interventions and how such interventions might negatively impact women by attempting to erase us and "brand us with names that are offensive to our ears." Even she did not imagine the exponential speed at which it would spread or the level to which it would grow to dictate new social norms, laws, language, and culture.

Her new book presents evidence that those risks that she had warned against are happening and are proving to be much worse than even she had expected or imagined. Drawing on testimonies from transitioning and de transitioning trans identified persons, she argues that transgender ideology and its development of the new disease they termed gender dysphoria is nothing other than the normalisation of patriarchal gender roles and stereotypes. In her words:

Amputating a healthy penis or breasts, being dependent on cross-sex hormones, and often embarking on secondary surgical journeys to alter voice or appearance, is a walking tribute to the power of patriarchal definitions of masculinity and femininity, which teach all of us that in a gender-defined culture it is easier to change your body than to change your society (Emphasis mine, p21).

Her book demonstrates how, across all levels of society, transgenderism has become the most powerful political ideology driving significant social change. The speed 
to achieve such changes has in part been possible because of the enormous financial resources that proponents of transgenderism possess or have been given. Their shrewd and manipulative use of self-pity, including false claims to risks of suicide if the status of being transgender is not recognised and accepted, comparisons to civil rights movements, imposition on the LGB platform, and their virulent suppression of all dissent or criticism of its ideology assisted them in gaslighting and convincing significant segments of the media to their "cause." Despite the huge impact on women of transgender ideology, debate, criticism, and dissent have been effectively sidelined and excluded from decision making processes on transgender policies and laws, with devastating effects for women.

Raymond herself has been targeted and punished for daring to criticise transgenderism and for having and expressing a dissenting view. Many other critics, both private and public, academics, journalists, activists, have faced physical and verbal abuse for daring to question the validity of transgenderism and its ideology. The mere act of expressing a dissenting view or requesting a debate on transgenderism has been sufficient to cause feminist scholars to lose their jobs and for them to become the target of vicious off and online abuse and threats.

Transgender ideology's violent suppression of dissent and of critics who dare to question the mistruths and lies that it feeds to the public ensures that most people are not aware of the danger of transgenderism and its ideology. In Raymond's words:

Within the public at large, transgenderism is not well understood. Few are aware what surgical 'reassignment" entails and what is happening to children, among them a rising number of young girls who are being "treated" in gender identity clinics for alleged gender dysphoria, put on puberty blockers, and encouraged to start hormone treatments at puberty. Most people don't know there is an international debate, especially about medicalizing children who say they are "born in the wrong body" (p. 19).

This above all, demonstrates the irreversible damage being done to children, who are being used systemically as the foundation of transgender ideology. Targeting and using children has always been the foundation of dogmatic ideologies to ensure their sustainability and transgenderism is no less in such use. As Raymond recognises in her book:

In an analysis of a report called Only Adults? Good Practices in Legal Gender Recognition for Youth, British journalist James Kirkup reveals in detail the strategy that has made the transgender platform successful.... Kirkup documents how transgender activists pushed the legal envelope in various countries to achieve legal changes that allow young children to change their gender "without adult approval and without needing the approval of any authorities" (p.56).

The report contains an explicit acknowledgement that it was written so that activists can use the tactics listed to advance transgender youth rights. It includes various "best practices" to ....... circumvent parental and legal approval such as the following:

States should take action against parents who are obstructing the free development of a young trans person's identity in refusing to give parental authorisation when required." "Get ahead of government agenda" (p. 56). 
Raymond's book touches on some of the significant harms of transgenderism including the harmful health implications of the medicalisation of otherwise healthy children and adults, the gaslighting of children who are being taught that their everyday reality is not real but could be whatever they may decide to change it to be - resulting in confusion about their lived realities, and the denial of science, where they attempt to replace biology with their subjective definition of reality as a "feeling" of what they believe they are. As Raymond states:

There is no scientific reason to teach students that boys can become girls or girls can become boys. This is perverting science." She goes on to quote Andrew Sullivan, who wrote "It takes the experience of less than one percent of humanity and tries to make it explain the 99 percent of their peers. It's nuts; and it will confuse children, particularly gay children (p. 181).

However, the most important aspect and core of Raymond's book is her exposure of the harm to women of transgender ideology.

She demonstrates how this extremely alarming and damaging ideology is succeeding in its attempts at the erasure of women as a social group, its reinforcement of patriarchal stereotypes and gender roles. In its attempts to erase women as a social group, terminology has been a tool which has been used effectively to begin the cancellation of women as a class. The renaming of women as cis-women and other such obnoxious and insulting names, the removal of sex and its replacement with gender as a determinant of identification has had skewed results in all aspects of society from education to criminal justice, from statistics and data to sports, from culture to language.

Starting with some of the medical and health harms, she documents the significant health risks of the physical and surgical interventions carried out during transition. Citing a 2016 study, she writes:

As for breast binders, a 2016 study entitled "Health Impact of Chest Binding Among Transgender Adults: A Community-Engaged, Cross-Sectional Study" found that over 97 percent of respondents reported at least one of the 28 negative outcomes attributed to binding, including pain, overheating, and shortness of breath. A substantial percentage even reported rib fractures (in Peitzmeier et al, 2016). Another harmful effect was back pain. The more frequent the binding, the more it was associated with negative outcomes. Breast binding involves compression of chest tissue, scarring, and dermatological problems caused by binders, elastic bandages and duct tape or plastic wrap (in Peitzmeier et al, 2016). Additional consequences of breast binding, reported by individuals not part of the study, are lower lung capacity and permanent shoulder "dents" (p. 118).

Why would anyone want to condemn women to this sort of mutilation and lifelong torture in the name of an amorphous and subjective notions of gender identity? Where these types of practices exist in other societies, usually in the so-called "third world" countries, they are slammed as mutilation and as extremely negative practices that must be condemned and eliminated. Why then are Western countries not seeing the harms caused by these practices to their own citizens? Such is the power of the transgender lobby it has been able to convince policy and law makers of the validity of such harms. Raymond also describes other harmful effects of transition. She explains: 
Scott Newgent, a trans-identified man (woman) who transitioned at age 42, creates a picture of the "brutal process" of undertaking phalloplasty: "During my own transition, I had seven surgeries. I also had a massive pulmonary embolism, a helicopter life-fight ride, an emergency ambulance ride, a stressinduced heart attack, sepsis, a 17-month recurring infection due to using the wrong skin during a (failed) phalloplasty, 16 rounds of antibiotics, three weeks of daily IV antibiotics, the loss of all my hair, (only partially successful) arm reconstructive surgery, permanent lung and heart damage, a cut bladder, insomnia-induced hallucinations-oh and frequent loss of consciousness due to pain from the hair on the inside of my urethra. All this led to a form of PTSD that made me a prisoner in my apartment for a year. Between me and my insurance company, medical expenses exceeded \$900,000" (Newgent, 2020, pp 33-34).

\section{Simply mind-blowing!}

The extremely harmful impact of transgenderism to women includes women being obliged to share their spaces with men who identify as women. It is pertinent to recall the reports of women and girls in a Korean spa being forced to accept the presence of a male based solely on the fact that he self-identifed as a woman. The objectification of women, the transgender erasure of lesbians, promotion of prostitution, promotion of violence, the erasure of sex crimes committed against women by men, the obnoxiousness of which is the requirement that women who are survivors of rape and sexual violence are obliged to address the perpetrator as she, solely because the said perpetrator decides to self-identify as female. Writing about the harms of transgender ideology and the UK government turn around on allowing men who selfidentify as women to be placed in women's prisons, Richard Garside (2020) wrote in his article:

A welcome shift in the transgender debate much of what I have written above will be dismissed as so much transphobia by a certain type of activist. After a few years of being at the receiving end of such accusations, I view them as what they really are: the secular equivalent of denunciations for heresy Garside.

The invasion of women's sports by self-identifying males are effectively shutting women out of sports and depriving them of the benefits connected to it.

There are so very many ways in which transgenderism and transgender ideology is harmful to women and Raymond's book convincingly takes us through all areas and arguments in support of her arguments.

Her book is not a declaration of hate against trans-identified persons nor of fear of them. In Raymond's words:

Radical critics of transgenderism are not afraid of trans-identified persons nor do we hate them. As writer Susan Moore has made clear, "We fear what we have always feared: male violence, in whatever cosplay it chooses. We fear losing our incomes. We fear that womanhood is such a scary place that young women will be medicated out of it" (Moore, 2020, p. 10).

In conclusion, it is evident that the shift of transgenderism and transgender ideology from a marginal, peripheral one to the mainstream has been incredibly swift and encompassing, penetrating all levels of society with its impositions and demands. 
Transgender ideology has found fertile ground in today's current atmosphere of alternative truth where some segments of society push the belief that the repetition of mistruths, half-truths, and outright lies is all that is needed to make a lie become truth. With regards to transgenderism, that belief seems to have gained traction. Increasingly, many governments, especially in the global West, are anxiously running behind this warped sense of reality, promulgating laws and policies to compel their citizens to accept that our lived daily reality is only a figment of our imagination. They would have us accept the imposition of the subjective feelings of a minuscule segment of society who want their very subjective belief and definition of who they claim to be, completely divorced from the biological reality of who they really are, to be accepted as the reality of everyone else. A government imposed alternative world where reality is interpreted through the prism of self-declarations and self-identification and not through empirical scientific evidence of what is and of the world we inhabit.

Janice Raymond's book describes the reasons why that alternative world is deadly and unacceptable. This is an educative, informative, and groundbreaking book, a must read and an essential part of everyone's library in today's world and for the future.

\section{AUTHOR BIOGRAPHY}

Esohe Aghatise is a human rights activist and UN Expert on Trafficking. She is the founder and Executive Director of Associazione Iroko Onlus, providing services to victims of sexual violence and trafficking in Italy. She is a member of the boards of the Coalition Against Trafficking in Women (CATW), the Young Women's Christian Association (YWCA YWCAUCDG), Italy Chapter, the Edo Women's Development Initiative in Benin City, Nigeria and is a Trustee of the Centre for Women's Justice, UK. Ms Aghatise is a founding member of Edo State (Nigeria) Task Force on Trafficking in Human Beings. She is a member of the Organisation for Security and Cooperation in Europe's Office for Democratic Institutions and Human Rights' National Referral Mechanisms' Advisory Group (Anti-Trafficking Handbook) since 2018 and contributed to the new version of the NRM Handbook on provision of support to victims of trafficking. She has received several awards for her work including being honoured in 2007 by the US State Department as a "Hero in the fight against modern day slavery." Ms Aghatise produced a short film on trafficking entitled "Journey of No Return" (Viaggio di Non Ritorno), which is being distributed in different parts of the world as a preventive measure against trafficking.

\section{RECOMMENDED CITATION}

Aghatise, Esohe. (2022). A feminist challenge to transgenderism. A review of Doublethink: A feminist challenge to transgenderism. Dignity: A Journal of Analysis of Exploitation and Violence. Vol. 7, Issue 1, Article 5. https://doi.org/10.23860/dignity.2022.07.01.05 Available at http://digitalcommons.uri.edu/dignity/vol7/iss1/5.

\section{REFERENCES}

Garside, Richard. (2020, September 25). A welcome shift in the transgender debate. Crime and Justice. https://www.crimeandjustice.org.uk/resources/welcome-shifttransgender-debate 